University of Wollongong

Research Online

Faculty of Social Sciences - Papers (Archive) Faculty of Arts, Social Sciences \& Humanities

2016

Geographies of global issues: Change and threat in young people's lives

Natascha Klocker

University of Wollongong, natascha@uow.edu.au

Nicola Ansell

Brunel University

Follow this and additional works at: https://ro.uow.edu.au/sspapers

Part of the Education Commons, and the Social and Behavioral Sciences Commons

Research Online is the open access institutional repository for the University of Wollongong. For further information contact the UOW Library: research-pubs@uow.edu.au 


\title{
Geographies of global issues: Change and threat in young people's lives
}

\begin{abstract}
Children and young people, throughout the world, are experiencing a time of immense and rapid change environmental, social, political, economic, and cultural. This chapter introduces readers to a volume entitled Geographies of Global Issues: Change and Threat, which is part of the Geographies of Children and Young People series. It provides an overview of the chapters contained in that volume and outlines four key themes that run across those chapters. First, children's geographies are also - fundamentally about adults. It does not make sense to do children's geographies, without taking the perspectives of adult decision-makers into account. Second, children and young people are agents of change - but their lives are also powerfully influenced by broader structures and processes over which they have little say. Children's geographers need to balance their attentiveness to the microscale of children's everyday lives, with a careful and sustained focus on the bigger picture. Third, change is not just an external force that impacts on children and young people's lives. Children and young people contribute to diverse global, regional, and local changes and threats. It is important to bear in mind that their contributions to change are not always benign or beneficial. Fourth, while change can threaten or undermine children and young people's wellbeing, it can also engender opportunities. Children's geographers have an important role to play in scratching beneath the surface, to uncover sources of possibility and optimism amidst upheaval.
\end{abstract}

\section{Keywords}

issues, global, lives, geographies, people, change, threat, young

\section{Disciplines}

Education | Social and Behavioral Sciences

\section{Publication Details}

Klocker, N. \& Ansell, N. (2016). Geographies of global issues: Change and threat in young people's lives. In N. Ansell, N. Klocker \& T. Skelton (Eds.), Geographies of Global Issues: Change and Threat (pp. 1-17). Singapore: Springer. 
Klocker, N. and Ansell, N. (2016) 'Geographies of global issues: change and threat in young people's lives' in Ansell, N., Klocker, N. and Skelton, T. (Eds) (2016) Geographies of Global Issues: Change and Threat, Vol. 8 of Skelton, T. (ed) Geographies of Children and Young People, Springer, Singapore.

\title{
http://www.springer.com/us/book/9789814585538
}

\section{Geographies of global issues: change and threat in young people's lives}

Natascha Klocker (University of Wollongong), Nicola Ansell (Brunel University)

\begin{abstract}
Children and young people, throughout the world, are experiencing a time of immense and rapid change - environmental, social, political, economic and cultural. This chapter introduces readers to a volume entitled Geographies of Global Issues: Change and Threat, which is part of the Geographies of Children and Young People series. It provides an overview of the chapters contained in that volume, and outlines four key themes that run across those chapters. First, children's geographies are also - fundamentally - about adults. It does not make sense to do children's geographies, without taking the perspectives of adult decision-makers into account. Second, children and young people are agents of change - but their lives are also powerfully influenced by broader structures and processes over which they have little say. Children's geographers need to balance their attentiveness to the micro-scale of children's everyday lives, with a careful and sustained focus on the bigger picture. Third, change is not just an external force that impacts on children and young people's lives. Children and young people contribute to diverse global, regional and local changes and threats. It is important to bear in mind that their contributions to change are not always benign or beneficial. Fourth, while change can threaten or undermine children and young people's wellbeing, it can also engender opportunities. Children's geographers have an important role to play in scratching beneath the surface, to uncover sources of possibility and optimism amidst upheaval.
\end{abstract}

\section{INTRODUCTION}

Children and young people's lives are profoundly shaped by diverse global processes including economic globalisation, cultural change, international development and environmental degradation and upheaval. In 2015, the world's population included 1.9 billion children below 15 years of age, constituting 26 per cent of the total population. Nine per cent of the world's 
population was under five years of age (United Nations Department of Economic and Social Affairs, 2015). The world's youthful populations are unevenly distributed, in ways that do not reflect the distribution of the global adult population. In Africa, for instance, children under 15 accounted for 41 per cent of the population in 2015, and young people (aged 15-24) accounted for a further 19 per cent (United Nations Department of Economic and Social Affairs, 2015). Children and young people thus make up 60 per cent of the population of the African continent. Three geographical regions alone (Africa, Latin America and the Caribbean, and Asia) accounted for 1.7 billion of the world's 1.9 billion children in 2015 (United Nations Department of Economic and Social Affairs, 2015). These are also the places where many of the global issues, changes and threats discussed in this volume, intersect in complex and challenging ways with existing patterns of socio-economic vulnerability on the ground.

Today's children and young people are growing up in a world of rapid and profound change. The volume on Geographies of Global Issues: Change and Threat explores this world of change through two broad categories. The first section on Globalisation: Processes and Impacts focuses on globalisation as a set of related processes - economic, political, social and cultural - and the impacts these are having on children and youth, as well as the ways in which they involve young people as actors. Recent decades have witnessed an unprecedented speed of technological change, enabling a large part of the world's population to engage in instantaneous global communication. Global connections extend beyond simple communication, however, as the world becomes increasingly 'connected by flexible capital, mobile labour and transnational families' (Aitken et al. 2008:3). Distance and political borders are losing their relevance to the operation of firms, as millions of dollars can be transferred to distant countries in seconds. While globalisation is enabled by technology, it is driven by powerful actors. Global corporations seek out access to resources, labour and markets around the world, drawing on and bolstering the neoliberal ideology that pervades most international institutions and national governments. And as a product of economic change, the movement of labour, of goods and of ideas in turn produces social change. These processes are assisted and stimulated by the internet and diversifying forms of media which facilitate near-instant responses to happenings worldwide. Not all is directly driven by global markets: governments, non-governmental organisations and international agencies still seek to make change in the interests of the poor, but global development agendas are becoming progressively more intertwined with those of capital and markets (Ansell forthcoming 2016). All of these processes of change are transforming the contexts of children's lives, the work patterns, 
consumption, lifestyles and values of their families and their own roles as economic and social actors.

The second section, Environmental Knowledge, Change and Issues, foregrounds environmental change and upheaval. While environmental issues other than climate change are given consideration, the threat posed by global climate change looms large over children and young people's lives, and over these chapters. In their lifetimes, today's children and young people will witness profound - perhaps catastrophic - changes to the global climate. Many scientists already think it will be impossible to avoid global warming of $2^{\circ}$ Celsius above preindustrial levels, which has been identified as the threshold between 'dangerous and extremely dangerous climate change' (Anderson and Bows 2011: 41, Head 2016). If current rates of greenhouse gas emissions persist, then $4-6^{\circ}$ Celsius of warming is a possibility. While this temperature difference sounds minimal, it is equivalent to that between now and the last ice age, but in the opposite direction (Head, 2016). The challenges posed by a changing climate are wide-reaching. More intense disasters (storms, floods, cyclones) and prolonged and frequent droughts, sea-level rise, declining food and water security, and changing geographical distributions of disease will shape children and young people's lives and wellbeing over the coming decades. Transformational changes to everyday life will be required (Head 2016, Park et al. 2012, Stafford Smith et al. 2011, Toole et al., 2015). Climatic changes will also interact with a range of other harmful anthropogenic impacts on environments and species throughout the world: pollution, land and water degradation and biodiversity loss.

For all of these reasons, children and young people's everyday lives throughout the $21^{\text {st }}$ Century are - and will be - manifestly different from those lived by their parents and grandparents. Contemporary social, economic and environmental challenges make children and young people vulnerable and expose them to harm. Equally, they compel children and young people to become instigators of change across geographical scales, from the household to the globe. Children and young people need to be adaptive and resourceful: economically, socially and emotionally.

\section{OVERVIEW - GEOGRAPHIES OF GLOBAL ISSUES: CHANGE AND THREAT}

The chapters in this volume are diverse in their content and geographical scope. Topics covered include: childcare, coffee production, migrant workers, youth entrepreneurship, football, skateboarding, education, HIV/AIDS, internet use, household environmental sustainability, more- 
than-human encounters, Indigenous knowledge, energy futures, intergenerational responsibilities, agriculture, health, earthquakes, peak oil, gender, pollution and emotional responses to a changing climate. The geographical scope of these works covers all continents (except Antarctica), and 16 countries. Notwithstanding this diversity, four over-arching themes are carried through the volume.

First, children's geographies are also - fundamentally - about adults (Hopkins and Pain 2007). The United Nations Convention on the Rights of the Child (UN 1989) has enshrined participation as fundamental to the best interests of the child. Article 12(1) specifies:

States Parties shall assure to the child who is capable of forming his or her own views the right to express those views freely in all matters affecting the child, the views of the child being given due weight in accordance with the age and maturity of the child.

Over the ensuing decades, academic research - including a body of work known as the 'new social studies of childhood', alongside children's geographies - has emphasised and prioritised children and young people's participation rights and agency (Aitken 2001; Alanen 1988; James et al. 1998; Matthews and Limb 1999; Percy-Smith and Thomas 2010; Prout and James 1990). While the chapters in this volume agree that children and young people are generally capable of expressing informed opinions about their own lives - and of contributing in diverse ways to social, economic and environmental change - adults remain important informants for children's geographers. This is not least because adults retain a great deal of decision-making power over children and young people's lives, and - at a broader scale - are responsible for many of the actions (and inactions) that jeopardise children's wellbeing. A clear example here relates to the incapacity of global leaders - up until the COP21 agreement in Paris in 2015, to adopt a comprehensive and adequate global agreement on reducing greenhouse gas emissions. At a more intimate scale, the organisation of childcare is most often the responsibility of adults, who are increasingly required to make complex arrangements for their children in contexts of transnational migration. Children and young people's wellbeing now (and into the future) is directly tied to the actions of presentday adults. A number of chapters of the volume, Geographies of Global Issues: Change and Threat reflect on the circumstances confronting children and young people, primarily through the eyes of adult informants - in particular, parents. They also make links to the broader structures that circumscribe children and young people's agency (Klocker, 2007), as discussed further below. 
A second - and related - theme that emerges throughout the chapters in this volume is that children's geographers need to pay careful attention to the broad structures and processes (economic, social, political, environmental) that impact on children and young people's lives. Over the last two decades, children's geographers have arguably emphasised children and young people's agency, to the neglect of the 'big picture' (Ansell, 2009; Holt and Holloway 2006). Yet children and young people's agency is often limited to the micro-scale - to everyday interventions in households, families and communities. These interventions are important, as noted in a number of chapters in this volume (e.g. Langevang, 2016; Esson, 2016; Malone, 2016; Stratford, 2016; Stanes and Klocker 2016). However, several other chapters in the volume join a growing call within children's geographies to think and research beyond the dominant emphasis on children and young people's agency and to look to the global scale (Aitken et al. 2008; Ansell, 2009; Hopkins and Alexander 2010). These include Abebe (2016); Wells (2016); Ansell (2016); Davies, Tabucanon and Box (2016); and Tranter and Sharpe (2016). Opportunities for children and young people to intervene in broad, structural processes (such as decision-making concerning public spending, or the development of laws and policies by national governments or international institutions) are often minimal. This means that efforts to advance children's interests and rights should not (indeed, cannot) depend solely on children and young people enacting youthful agency. Related to the first point above, children's geographers ought to pay greater heed to actors other than children, and to macro-scale processes (over which children and young people still have very little say), in order to effect the deep changes to global systems that are needed to respond to contemporary global issues and threats. Children's geographers need to take care not to let adults (and the global corporations and organisations that they lead) 'off the hook' through a dominant focus on children and young people's agency. Evidence of children and young people's agency should not excuse adult decision-makers from taking action, now.

Third, change is not just an external force that impacts on children and young people's lives. Children and young people contribute to the changes and threats outlined above - for better and for worse. Several chapters in this volume highlight important contributions that children have made to improve social, economic or environmental outcomes - for instance, through carefully planning an urban neighbourhood that is encompassing of non-humans (Malone, 2016); or by driving community adaptive responses to climate change (Towers, Ronan and Rashid, 2016). It is often through necessity that young people play active roles in responding to change, substituting 
for adult workers in the home or in agriculture when faced with economic hardships due to falling global coffee prices (Abebe, 2016), or seeking out opportunities for entrepreneurship as formal sector employment fails to materialise (Langevang, 2016). Yet, children and young people's agency is not always a benign or beneficial force. This is evident, for instance, in the contributions that children and young people in the Global North make to unsustainable and wasteful patterns of resource consumption, associated with a desire to keep up with the latest trends in technology and fashion (see Stanes and Klocker, 2016); or the ways in which some young entrepreneurs exploit their peers in order to achieve economic gain (Young and Kumar, 2016).

The fourth and final theme that runs across this volume recognises that contemporary global changes present profound challenges to children's wellbeing. But they may also engender opportunities. Thus, for instance, the disruption posed by 'peak oil' may create possibilities for children to live healthier lives - characterised by greater use of active transport and improved freedom of movement in urban spaces (see Tranter and Sharpe, 2016). So too, efforts to mitigate the worst effects of climate change may come with important health co-benefits for children and young people (see Towers, Ronan and Rashid, 2016). Moreover, some global processes, like the communications afforded via the internet, are enabling some young people to engage politically and socially in positive ways in relation to people and events in distant places (see Rye, 2016).

\section{Globalisation: Processes and Impacts}

Young people's lives are increasingly subject to a range of global processes operating in the economic, cultural, political and social realms. Through these processes children and youth are incorporated in diverse ways into the economic and social life of nations, communities and households. Global processes impinge on young people in ways that range from the arrangements of childcare and education, and development interventions to assist those deemed particularly in need, to young people's involvement in economic and entrepreneurial activities and even the construction of their subjectivities. Global processes are, however, expressed differently in the very diverse contexts in which young people live, and elicit varying responses from young people themselves.

The chapters gathered in the section on Globalisation: Processes and Impacts, explore a range of global processes and their impacts on children and youth of different ages, from infancy to young adulthood. They draw on sources of empirical research conducted in settings across the world to 
consider how global processes play out in particular contexts, shaping young lives and incorporating them into global change. The section begins with five chapters that specifically address the outcomes of neoliberal economic transformation, and in particular the ways in which this shapes young people's livelihood activities (Abebe, 2016; Young and Kumar, 2016; Langevang, 2016), rights (Rodriguez et al, 2016) and the organisation of childcare (Kusakabe and Pearson, 2016; Cox, 2016). A second group of chapters (Esson, 2016; Rye, 2016; Baillie Smith et al, 2016) picks up a theme that has been touched on in relation to the impacts of neoliberal economic change: the ways in which various processes of globalisation (including internet technology, education and opportunities for travel) shape young people's subjectivities. The final four chapters in this section (Riley and Salie Hara, 2016; Norman, 2016; Wells, 2016; and Ansell, 2016) examine the ways in which the subject of the 'global child' is constructed through the practices in particular of international development, the ways in which this abstract construct fails to engage with the lived lives of young people, and the extent to which it serves particular global agendas.

In focusing on neoliberal economic change and its impacts on young people's livelihoods, rights and care, six of the chapters in the first section (described below) recognise that most nation states have, in recent decades, become progressively more closely dependent on the global economy. Production is increasingly geared to export, services are provided for consumers and clients overseas and a high proportion of formal employment is in sectors dominated by international investment. Moreover, in their quest for inward investment and an expanding global role, nations adopt heightened forms of securitisation. Several authors in this section of the volume engage directly with the outcomes of such processes for young people.

Tatek Abebe, in his chapter on 'The Political Economy of Coffee Production and Children's Work in Post-Socialist Ethiopia', argues that political economy is a crucial determinant of young people's wellbeing. His chapter focuses on Ethiopia, where rural life has become more dominated by cash crop production, and particularly coffee, since the fall of the socialist regime in 1991. Unstable prices on global markets have had serious consequences for family livelihoods. Coffee growing took land away from women's food crop growing, making households more dependent on the market. However, with coffee prices inadequate to support households, both men and women have needed to seek other sources of income, a situation that has relied on children performing key household responsibilities and an extension in the scope, duration and intensity of their work. 
By contrast, Stephen Young and Satendra Kumar their chapter, 'Learning to Improvise: Youth Entrepreneurs in Liberalizing India', and Thilde Langevang in her chapter, 'Generation Entrepreneurship: Youth, Enterprise and Socio-Economic Change in Urban Ghana', note that in India and Ghana respectively neoliberal economic restructuring of urban labour markets has reduced young people's opportunities to find work. In both countries, relatively high economic growth has been largely jobless and, under neoliberal policies, opportunities for employment by the state are vanishing. With few prospects of formal sector employment, some of the Indian youth that Young and Kumar discuss persist in acquiring more education. For many, however, as with their peers in Ghana, there is little alternative but to pursue entrepreneurial activities: a course of action actively promoted by the Ghanaian government, albeit often with limited success.

Many of the 'emerging powers' of the global economy view Mega-Sporting Events as a lucrative means of attracting economic investment, stimulating growth and taking a more prominent role on the global stage. Global security concerns, however, have led to a range of interventions that have prejudicial outcomes for the rights of poor children, as Andrea Rodriguez, Lorraine van Blerk, Fernando Fernandes, Jon Mendel, Irene Rizzini, Peter McEleavy and Nicholas Fyfe describe in their chapter on 'Mega-Sporting Events, Rights and Children's Everyday Lives: Exploring the Impact of the Brazil 2014 FIFA World Cup'. Their research around the impacts of the staging of the World Cup in Brazil points to a range of problematic outcomes for young people.

Economic globalisation is expressed not only in economic restructuring within national boundaries, but also in new economic patterns between nation states. Where there are significant economic inequalities between neighbouring countries, border regions become areas of intense economic activity. In Thailand, factories established close to the border with Burma attract Burmese workers willing to accept lower wages than their Thai counterparts. In their chapter on 'Juggling Children Across Borders: Childcare Arrangements of Burmese Migrant Workers in Thailand', Kyoko Kusakabe and Ruth Pearson explore how these largely female factory workers determine where and how to raise their children, drawn by free and better education in Thailand, but deterred by their precarious immigrant status and the absence of family networks.

The care of children is itself a growing focus of the global economy. The concept of Global Value Chains that is used by Kusakabe and Pearson to illuminate the links between Burmese workers, Thai factories, and the global marketplace has been extended to analyse how a care economy has 
emerged in which workers from one society undertake international migration in order to care for the children of another, leaving their own children in the care of yet others. These Global Care Chains, discussed by Rosie Cox in her chapter on 'Migrant Domestic Workers and the Globalisation of Childcare', operate in part to allow parents in wealthier countries to fully participate in the global economy, but also to ensure that their children are intensively parented in a way that maximises the children's future prospects of economic success. As with many of the chapters in this volume, it is clear that economic, cultural and social processes are intimately tied together, with economic change driving cultural change that in turn drives other forms of economic change, all impacting in different ways on children in different places.

In addition to its practical impacts on their lives, globalisation reconstructs young people's subjectivities, as outlined in the next three chapters. Beyond trade in goods and services that takes place through Global Value Chains and Global Care Chains, an emerging aspect of economic globalisation is speculative financial investment, with investors seeking out potential sources of profit in the global economy. James Esson, writing on 'Competing Fields of Play: Male Ghanaian Youth and Football as a Vehicle for Development', considers the lives of young Ghanaian footballers many of whom are effectively commodities in a global market. Talented youth league players are recruited by local amateur clubs that hope to sell them to European professional clubs. The European clubs in turn also see African youth as a speculative investment; once trained they might fetch a high resale value. In this context, Ghanaian youth are clearly a commodity being traded; however, Esson also emphasises the role of youth as entrepreneurs in this process, owning amateur football clubs and trading young players on the international market. This has strong resonances with Young and Kumar's (2016) examination of the new market in higher education in India, where some young people invest their time in studying, while others give up their pursuit of qualifications and paid employment, instead becoming entrepreneurs in the education market, establishing their own colleges to profit from the educational desires of other youth.

The chapters by Esson, Langevang and Young and Kumar all clearly emphasise the opportunities for young people to construct new subjectivities as entrepreneurs in the global economy. Esson (2016) draws on Foucault to consider how, in Ghana, those who pursue a career as a professional footballer represent the 'entrepreneurs of the self' that neoliberalism desires, investing in their own bodies to take advantage of the opportunities the global market place affords. There are other global processes, too, through which young people's subjectivities, and not merely their 
livelihoods and care arrangements, are shaped. Ståle Rye in her chapter, 'Young People's Construction as Global Citizens through Internet Use', examines how the internet enables young people to interact with others around the world, and may enable them to construct themselves as global citizens. However, for young people to be active global citizens - members of a global political community - Rye argues that internet access alone is insufficient but needs to be developed through education. In their chapter on 'Young People's Subjectivities and Geographies of Development: Education, International Volunteering and Citizenship', Matt Baillie Smith, Nina Laurie, Eleanor Brown, Mark Griffiths and Darryl Humble also consider young people's construction of themselves as global citizens. They explore in particular the role of a number of practices through which British youth encounter the Global South, notably opportunities for volunteering overseas and development education. These practices need to be understood in context. International volunteering, for instance, is often organised by faith-based organisations. However, a key motivator behind the construction of global subjectivities is, according to Baillie Smith et al., their functional role in the neoliberal economy. Those promoting development education and volunteering often see it as enabling young people to build skills and competencies for an interconnected world. The Global South (as constructed through education, media and tourism) is a convenient setting against which to develop desirable attributes. As with the young Ghanaian footballers, Western youth are, through these practices, at least in part investing in their own identities for a competitive world. Not all are fully complicit in this form of subjectification, however, but choose to contest and redefine the ways they are positioned.

The last set of chapters in the section on Globalisation: Processes and Impacts focus on the construction of the subject of the 'global child' through the purposive practices of international development. The subjectification of young people is not simply an outcome of young people's interactions with global processes but is produced through the discourse of international media and institutions and through international development. The Millennium Development Goals, for instance, draw on the abstract discursive construct of a global child. In impoverished Malawi, as Liam Riley and Chimwemwe Salie Hara explain in their chapter ('Africa's Vulnerable Children and the Millennium Development Goals: Experiences and Interventions in Malawi'), this abstract construct fails to illuminate or engage with the material realities of children's lives. Such discrepancies between the imaginaries of the global scale and local contextual challenges can lead to ambiguous outcomes for children. Amy Norman, writing on 'Childhood in 'Crisis' in the Era of AIDS: Discourses of Concern, Orphanhood, and Policy in Southern Africa', likewise critiques the 
way in which the globalised notions of childhood that pervade international media, development policy and donor agendas lay at the basis of a discourse of 'crisis in childhood' that shaped interventions towards southern African children deemed to be orphaned by AIDS. It enabled - or required - such children to be understood as victims 'at risk' and in the process unhelpfully denied their agency and the competence of their families to provide and care for them.

In her chapter on 'Governing the Global Child: Bio-Politics and Liberal Subjectivities', Karen Wells examines the origins of these global discourses of the child, arguing that liberalism and capitalism play important roles in their production and circulation. Drawing on governmentality theory, she traces the continuity between the child saving discourses that dominated relations between the global North and South in the twentieth century, and the increasingly prevalent child rights discourses promulgated by organisations such as UNICEF today. Both, she argues, have been put into place by non-state agents, are enacted through programmes, reports and statistics, and construct the child as a liberal subject in ways that fail to illuminate the role of political economy in shaping their material wellbeing or the capacity of their families to care for them.

Lastly, in 'Globalising Education from Christian Missionaries to Corporate Finance: Global Actors, Global Agendas and the Shaping of Global Childhoods', Nicola Ansell considers how global childhoods have been produced and shaped through the spread of one particular institution education - over the past two centuries. Ansell identifies a broad transition from missionary activity and colonialism to the growing roles of 'development' and increasingly corporate capitalism in determining the education that children receive. Through these processes, children and childhood serve global agendas and are, in the process, continually reconstructed.

\section{Environmental Knowledge, Change and Issues}

The second section of the volume on Geographies of Global Issues: Change and Threat focuses on environmental change. Specifically, it focuses on children and young people's exposure to climate change and other forms of environmental upheaval, and their engagement with environmental issues. It considers how environmental issues affect children and young people and, how children and young people - in turn - affect their environments (for better or worse). The chapters in this section pay particular attention to three key topics. The first five chapters explore children and young people's experiences of risk, vulnerability and resilience in the face of environmental hazards, pollution and climate change. The next four chapters foreground issues of 
intergenerational injustice and adults' responsibilities for ensuring a viable environmental future for children and young people. The section closes with four chapters that emphasise children and young people's knowledge of environmental problems, and their concerns and engagement with environmental issues as part-and-parcel of their everyday lives. Importantly, while climate change is a specific focus of the first set of chapters on risk, vulnerability and resilience, it is also discussed in a number of other chapters. Climate change permeates so many aspects of children and young people's lives today, and also their environmental futures.

As noted above, there are five chapters (described in the following paragraphs) that consider children and young people's experiences of risk, vulnerability and resilience in the face of environmental hazards, pollution and climate change. Briony Towers, Kevin Ronan and Mayeda Rashid ('Child health and survival in a changing climate: vulnerability, mitigation and adaptation'), provide an overview of the substantial health implications that climate change has for children and young people. They deploy a range of evidence to make a case that children are amongst the most vulnerable groups to climate change. Thus children and young people's needs must be placed at the front and centre of climate change mitigation and adaptation efforts. At the same time, Towers et al. recognise that children and young people must be included as stakeholders in these processes, to help ensure that actions taken meet their unique needs. In her chapter, 'Children, young people and climate change: a gender perspective', Agnes Babugura reviews evidence from a range of African countries to make a case that the impacts of climate change on children and young people are gendered. Many of these impacts are not direct effects of climate change, but occur as a result of increased pressure on livelihoods - for instance, increased school dropout amongst girls at times of drought, the increased burden of water collection (with implications for schooling, health and safety), harmful coping practices (such as prostitution), impacts on human dignity (relating to hygiene and sanitation), early and forced marriage, and poor nutrition. Intersections between gender and age make girls and young women particularly vulnerable to climate change. Babugura argues that girls and young women's unique experiences, concerns and capacities for enacting change need to be mainstreamed in climate change policy and interventions.

Writing on 'Young people and global climate change: emotions, coping and engagement in everyday life', Maria Ojala also foregrounds climate change, but shifts the geographical focus to Northern Europe. Her chapter argues that children and young people experience a range of 
complicated emotions relating to the threat of climate change. Ojala finds that many young people are worried about climate change, and that they develop a range of coping strategies in response to their concerns: problem-focused coping, emotion-focused coping and meaning-focused coping. Meaning-focused coping is particularly beneficial as it supports children and young people's sense of efficacy and engagement, and also their wellbeing. Trust in powerful societal actors (that is, adults) is also shown to be important in children and young people's capacity to cope with the threat of climate change.

The next two chapters of this volume shift the focus away from climate change, to consider different types of environmental hazards. In their chapter on 'Environmental ascription: industrial pollution, place and children's health and learning in the United States', Bruce London, Cristina Lucier, Anna Rosofsky and Helen Scharber draw attention to children and young people's exposure to pollution in the United States. They present empirical data to make a case that marginalised children and young people (specifically those from ethnic/racial minority backgrounds) carry a disproportionate burden of environmental pollution. London et al. also make a case that place intersects with race and class to limit the life chances of children and young people who live and/or go to school in polluted neighbourhoods. Exposure to specific chemicals increases childhood illnesses and undermines children's school performance scores. Their chapter thus draws attention to the challenges that minority children and young people face in breaking out of cycles of familial poverty - due to the polluted nature of their neighbourhoods.

The final chapter in the opening part of the section on Environmental Knowledge, Change and Issues by Claire Freeman, Megan Gollop and Karen Nairn ('Disasters, displacement and disruption: children and young people's experience of spatial change following disasters'), discusses children and young people's experiences in the wake of the 2010/2011 earthquakes in Christchurch, New Zealand. As a result of the earthquakes, some families moved away from Christchurch permanently, while others left for a period of time. Freeman et al. emphasise the importance of including children and young people's voices in post-disaster recovery processes, which necessitates moving beyond a view of children as passive victims of disasters. They make a case that children and young people can be active participants in the recovery process, and that the impacts of disasters on their sense of place needs to be better understood. 
The next group of chapters focuses on issues of intergenerational injustice and adults' responsibilities for ensuring a viable environmental future for children and young people. In their chapter on 'Children, climate change and the intergenerational right to a viable future', Kirsten Davies, Gil Tabucanon and Pamela Box make a strong case for children's intergenerational right to a viable future. They argue that climate change poses a threat to this right, and that children, young people and (as yet) unborn generations will bear the brunt of climate change over the coming decades. In addition to the rights of today's children and young people, Davies et al. demonstrate that future generations have rights, and that these need to be given greater consideration by present-day adults. Doing everything possible to prevent catastrophic climate change, then, is an issue of intergenerational justice and equity.

Paul Tranter and Scott Sharpe ('Global energy stress: challenges and opportunities for child friendly cities') begin by making a clear argument that children and young people's lives are profoundly influenced by the decisions made by adults - often without their consent. They note that these decisions are shaped by broader global forces, including around energy provision. Their chapter is framed around the end of cheaply available oil. However, in an important twist, Tranter and Sharpe argue that the implications of global energy stress will not be all bad. Children and young people's everyday lives will - in some respects - improve as a result of fuel scarcity. Tranter and Sharpe link the reduced availability and affordability of fuel to the creation of more childfriendly, walkable cities - in which children and young people's freedom of movement can be safely reasserted.

The chapter on 'Living in the future: environmental concerns, parenting and low-impact lifestyles', by Fiona Shirani, Chris Groves, Catherine Butler, Karen Parkhill, Karen Henwood and Nick Pidgeon, also focuses on adults as key decision-makers in relation to children and young people's presentday lives, and environmental futures. Using the case of families living in eco-villages, the chapter explains that the presence of children in families helps adults to make 'imaginative connections' to environmental futures. While parents in their study made the decision to move to an eco-village, they often did so for their children. They saw eco-village life as a way of enhancing their children's wellbeing in the present (as per the rural idyll), and of contributing to positive environmental futures through low-impact living. Further, by inculcating their children in off-the-grid, eco-village life, some parents also hoped to provide them with the 'survival skills' that may be necessary in an 
increasingly chaotic environmental future. Thus parents' perceptions of future catastrophe shaped the decisions that they made for their own children in the present-day.

The need for older generations to inculcate children and young people with knowledge of how to recognise and respond to environmental change is also a key concern in the chapter by Karen McNamara and Ross Westoby ('Inter-generational sharing of Indigenous environmental knowledge in the Torres Strait'). McNamara and Westoby describe a project undertaken with Indigenous Elders and school children in the Torres Strait Islands, off the north coast of mainland Australia. The project gave Indigenous Elders an opportunity to record their environmental knowledge, and lifetime experiences of environmental change - and to share their ways of reading environmental signals with younger generations. Although contemporary climate change presents new and different challenges, McNamara and Westoby argue that having access to a record of traditional knowledge, passed down by Elders, will provide a crucial resource for children and young people in the Torres Strait. While children's geographers have often foregrounded the importance of ensuring that children and young people have opportunities to express their views and knowledge, this chapter shows that children and young people also benefit from efforts to support intergenerational knowledge-transfer. This may be particularly important in Indigenous communities - as the environmental knowledge held by Elders has rarely been formally recorded, and is not part of standard school curricula relating to climate change. This set of chapters shares in common a focus on the important role of today's adults in safeguarding children and young people's environmental futures. They make it clear that children and young people's wellbeing now (and into the future) is directly tied to the actions and knowledges of present-day adults.

The final section of this volume emphasises children and young people's knowledge of environmental problems, and their concerns and engagement with environmental issues as partand-parcel of their everyday lives. First, Fraser Sugden and Samantha Punch, writing on 'Changing aspirations, education and migration: young people's declining agro-ecological knowledge in rural Asia', explore the pressures placed on children and young people's agro-ecological knowledges in rural Asia, as a result of broader structural issues relating to economic change, development, education and employment opportunities. Case studies from rural Vietnam, India and China show that many young people are moving to urban areas, due to changed aspirations, as well as ecological and economic stressors. When young people move to cities in search of formal 
education and non-agrarian careers, the implications for rural communities are profound. Importantly, migration undermines the intergenerational transfer of agro-ecological knowledge.

The next two chapters shift the geographical focus to Australia. Karen Malone ('Children's place encounters: place based participatory research to design a child friendly and sustainable urban development') explores the capacity of children and young people to be engaged in the design and development of a child friendly and sustainable urban development. Malone makes a case that children and young people learn through their engagement with local environments, and that the unique local environmental knowledges held by children and young people can provide important insights for urban planning and development processes. Through a participatory design process, children and young people in one community showed great responsiveness and openness to nonhuman affordances and encounters in their neighbourhood. When given the opportunity to participate in planning an urban development, they sought to ensure that these environmental qualities would be brought into the design. Malone concludes that children and young people who are given opportunities to participate in 'real life' projects, in place, can play important roles as environmental change agents. Elaine Stratford, in her chapter on 'Navigating a sustainable future: skateboarding as social and environmental praxis', also focuses on children and young people's engagements with their local places, in this case through the example of skateboarding. Skateboarding, as a transport option, has not been recognised as a viable alternative in broader planning processes in Australia. Yet Stratford argues that young people who skateboard are enacting a particular type of political agency - they are at once making a claim for their right to public space, and engaging in a unique, youthful and unheralded form of environmental praxis - as part of their everyday lives.

The final chapter of this volume, by Elyse Stanes and Natascha Klocker ('Young people in the Global North: environmental heroes or pleasure-seeking consumers'), provides a broad overview of children and young people's environmental knowledges and capacities, as well as their environmental 'weaknesses'. The chapter focuses on young people in the Global North, whose environmental credentials have been cast in paradoxical ways. On the one hand, they are considered more knowledgeable and concerned about the environment and climate change than older generations, but on the other hand they are frequently identified as reckless and wasteful consumers of resources (see also Collins and Hitchings 2012). Stanes and Klocker critically review literature on young people, consumption and environmentalism - foregrounding their roles in 
homes, schools and communities. The authors conclude that young people's environmental identities are complex. They call for greater attentiveness to the unique environmental sustainabilities of young people, which may open opportunities for thinking differently about consumption and environmentalism.

\section{CONCLUSION}

This introductory chapter has provided an overview of the volume on Geographies of Global Issues: Change and Threat (from the Geographies of Children and Young People series). It has also outlined the key themes that run across the chapters contained in the aforementioned volume. Children and young people face profound challenges - from global climate change to shifts in the global coffee trade; from eroding formal employment opportunities to the dangers of natural hazards and the health effects of pollution. This introductory chapter - and the other 26 chapters contained in the volume - have shown that children's geographers can provide important insights into a changing world by being attentive to children and young people, to adult decision-makers, to everyday life, to macro-scale structures and processes, to upheaval and threats - and, crucially, to opportunities amidst change.

\section{REFERENCES}

Abebe, T. (2016) 'The Political Economy of Coffee Production and Children's Work in Post-Socialist Ethiopia' in Ansell, N. and Klocker, N. (eds) Geographies of Global Issues: Change and Threat, Vol. 7 of Skelton, T. (ed.) Geographies of Children and Young People. Springer Singapore.

Aitken, S. (2001). Geographies of Young People. Routledge, London.

Aitken, S., Lund, R., and Kjørholt, A. (2008). Global Childhoods: Globalization, Development and Young People. Routledge, London.

Alanen, L. (1988) 'Rethinking Childhood', Acta Sociologica 31(1): 53-67.

Anderson, K. and Bows, A. (2011) 'Beyond 'dangerous' climate change: Emission scenarios for a new world', Philosophical Transactions of the Royal Society A, 369: 20-44.

Ansell, N. (2009) 'Childhood and the politics of scale: descaling children's geographies?' Progress in Human Geography, 33(2): 190-209.

Ansell, N. (2016) 'Globalising Education from Christian Missionaries to Corporate Finance: Global Actors, Global Agendas and the Shaping of Global Childhoods' in Ansell, N. and Klocker, N. (eds) Geographies of Global Issues: Change and Threat, Vol. 7 of Skelton, T. (ed.) Geographies of Children and Young People. Springer Singapore. 
Ansell, N. (forthcoming). Children, Youth and Development. Routledge, London (2 ${ }^{\text {nd }}$ Edition).

Babugura, A. (2016) 'Children, young people and climate change: a gender perspective' in Ansell, N. and Klocker, N. (eds) Geographies of Global Issues: Change and Threat, Vol. 7 of Skelton, T. (ed.) Geographies of Children and Young People. Springer Singapore.

Baillie Smith, M., Laurie, N., Brown, E., Griffiths, M. and Humble, D. (2016) 'Young People's Subjectivities and Geographies of Development: Education, International Volunteering and Citizenship' in Ansell, N. and Klocker, N. (eds) Geographies of Global Issues: Change and Threat, Vol. 7 of Skelton, T. (ed.) Geographies of Children and Young People. Springer Singapore.

Collins, R. and Hitchings, R. (2012) 'A tale of two teens: disciplinary boundaries and geographical opportunities in youth consumption and sustainability research', Area 44(2): 193-199.

Cox, R. (2016) 'Migrant Domestic Workers and the Globalisation of Childcare' in Ansell, N. and Klocker, N. (eds) Geographies of Global Issues: Change and Threat, Vol. 7 of Skelton, T. (ed.) Geographies of Children and Young People. Springer Singapore.

Davies, K., Tabucanon, G. and Box, P. (2016) 'Children, climate change and the intergenerational right to a viable future', in Ansell, N. and Klocker, N. (eds) Geographies of Global Issues: Change and Threat, Vol. 7 of Skelton, T. (ed.) Geographies of Children and Young People. Springer Singapore.

Esson, J. (2016) 'Competing Fields of Play: Male Ghanaian Youth and Football as a Vehicle for Development', in Ansell, N. and Klocker, N. (eds) Geographies of Global Issues: Change and Threat, Vol. 7 of Skelton, T. (ed.) Geographies of Children and Young People. Springer Singapore.

Freeman, C., Gollop, M. and Nairn, K. (2016) 'Disasters, displacement and disruption: children and young people's experience of spatial change following disasters', in Ansell, N. and Klocker, N. (eds) Geographies of Global Issues: Change and Threat, Vol. 7 of Skelton, T. (ed.) Geographies of Children and Young People. Springer Singapore.

Head, L. (2016) Hope and Grief in the Anthropocene: Re-conceptualising human-nature relations. Routledge, London.

Holt, L. and Holloway, S. (2006) 'Editorial: theorising other childhoods in a globalised world', Children's Geographies 4(2): 135-142.

Hopkins, P. and Pain, R. (2007) 'Geographies of age: Thinking relationally', Area 39: 287294.

Hopkins, P. and Alexander. C. (2010) 'Politics, mobility and nationhood: upscaling young people's geographies: introduction to special section', Area 42(2): 142-14.

James, A., Jenks, C. and Prout, A. (1998) Theorizing Childhood. Polity Press, Cambridge.

Klocker, N. (2007) 'An example of 'thin' agency: Child domestic workers in Tanzania', in E. Robson, R. Panelli and S. Punch (Eds) Young Rural Lives, Taylor \& Francis, New York, pp. 83-84. 
Kusakabe, K. and Pearson, R. (2016) 'Juggling Children Across Border: Childcare Arrangements of Burmese Migrant Workers in Thailand' in Ansell, N. and Klocker, N. (eds) Geographies of Global Issues: Change and Threat, Vol. 7 of Skelton, T. (ed.) Geographies of Children and Young People. Springer Singapore.

Langevang, T. (2016) 'Generation Entrepreneurship: Youth, Enterprise and Socio-Economic Change in Urban Ghana' in Ansell, N. and Klocker, N. (eds) Geographies of Global Issues: Change and Threat, Vol. 7 of Skelton, T. (ed.) Geographies of Children and Young People. Springer Singapore.

London, B., Lucier, C., Rosofsky, A. and Scharber, H. (2016) 'Environmental ascription: industrial pollution, place and children's health and learning in the United States' in Ansell, N. and Klocker, N. (eds) Geographies of Global Issues: Change and Threat, Vol. 7 of Skelton, T. (ed.) Geographies of Children and Young People. Springer Singapore.

Malone, K. (2016) 'Children's place encounters: place based participatory research to design a child friendly and sustainable urban development', in Ansell, N. and Klocker, N. (eds) Geographies of Global Issues: Change and Threat, Vol. 7 of Skelton, T. (ed.) Geographies of Children and Young People. Springer Singapore.

Matthews, H. and Limb, M. (1999) 'Defining an Agenda for the Geography of Children', Progress in Human Geography, 23(1): 61-90.

McNamara, K. and Westoby, R. (2016) 'Inter-generational sharing of Indigenous environmental knowledge in the Torres Strait' in Ansell, N. and Klocker, N. (eds) Geographies of Global Issues: Change and Threat, Vol. 7 of Skelton, T. (ed.) Geographies of Children and Young People. Springer Singapore.

Norman, A. (2016) 'Childhood in 'Crisis' in the Era of AIDS: Discourses of Concern, Orphanhood, and Policy in Southern Africa' in Ansell, N. and Klocker, N. (eds) Geographies of Global Issues: Change and Threat, Vol. 7 of Skelton, T. (ed.) Geographies of Children and Young People. Springer Singapore.

Ojala, M. (2016) 'Young people and global climate change: emotions, coping and engagement in everyday life' in Ansell, N. and Klocker, N. (eds) Geographies of Global Issues: Change and Threat, Vol. 7 of Skelton, T. (ed.) Geographies of Children and Young People. Springer Singapore.

Park, S., Marshall, N., Jakku, E., Dowd, A., Howden, S., Mendham, E. and Fleming, A. (2012) 'Informing adaptation responses to climate change through theories of transformation', Global Environmental Change 22(1): 115-126.

Percy-Smith, B. and Thomas, N. (eds.) (2010) A Handbook of Children and Young People's Participation. Routledge, London.

Prout, A. and James, A. (eds) (1990). Constructing and Reconstructing Childhood: Contemporary Issues in the Sociological Study of Childhood. Falmer Press, Basingstoke.

Riley, L. and Salie Hara, C. (2016) 'Africa's Vulnerable Children and the Millennium Development Goals: Experiences and Interventions in Malawi' in Ansell, N. and Klocker, N. (eds) Geographies of Global Issues: Change and Threat, Vol. 7 of Skelton, T. (ed.) Geographies of Children and Young People. Springer Singapore. 
Rodriguez, A., van Blerk, L., Fernandes, F., Mendel, J., Rizzini, I., McEleavy, P., Fyfe, N. (2016) 'MegaSporting Events, Rights and Children's Everyday Lives: Exploring the Impact of the Brazil 2014 FIFA World Cup' in Ansell, N. and Klocker, N. (eds) Geographies of Global Issues: Change and Threat, Vol. 7 of Skelton, T. (ed.) Geographies of Children and Young People. Springer Singapore.

Rye, S. (2016) 'Young People's Construction as Global Citizens through Internet Use' in Ansell, N. and Klocker, N. (eds) Geographies of Global Issues: Change and Threat, Vol. 7 of Skelton, T. (ed.) Geographies of Children and Young People. Springer Singapore.I

Shirani, F., Groves, C., Butler, C., Parkhill, K., Henwood, K. and Pidgeon, N. (2016) 'Living in the future: environmental concerns, parenting and low-impact lifestyles', in Ansell, N. and Klocker, N. (eds) Geographies of Global Issues: Change and Threat, Vol. 7 of Skelton, T. (ed.) Geographies of Children and Young People. Springer Singapore.

Stafford Smith, M., Horrocks, L., Harvey, A. and Hamilton, C. (2011) 'Rethinking adaptation for a $4^{\circ} \mathrm{C}$ world', Philosophical Transactions of the Royal Society A 369: 196-216.

Stanes, E. and Klocker, N. (2016) 'Young people in the Global North: environmental heroes or pleasureseeking consumers', in Ansell, N. and Klocker, N. (eds) Geographies of Global Issues: Change and Threat, Vol. 7 of Skelton, T. (ed.) Geographies of Children and Young People. Springer Singapore.

Stratford, E. (2016) 'Navigating a sustainable future: skateboarding as social and environmental praxis', in Ansell, N. and Klocker, N. (eds) Geographies of Global Issues: Change and Threat, Vol. 7 of Skelton, T. (ed.) Geographies of Children and Young People. Springer Singapore.

Sugden, F. and Punch, S. (2016) 'Changing aspirations, education and migration: young people's declining agro-ecological knowledge in rural Asia' in Ansell, N. and Klocker, N. (eds) Geographies of Global Issues: Change and Threat, Vol. 7 of Skelton, T. (ed.) Geographies of Children and Young People. Springer Singapore.

Toole, S., Klocker, N. and Head, L. (2016) 'Re-thinking climate change adaptation and capacities at the household scale' Climatic Change, 135(2), 203-209.

Towers, B., Ronan, K. and Rashid, M. (2016) 'Child health and survival in a changing climate: vulnerability, mitigation and adaptation' in Ansell, N. and Klocker, N. (eds) Geographies of Global Issues: Change and Threat, Vol. 7 of Skelton, T. (ed.) Geographies of Children and Young People. Springer Singapore.

Tranter, P. and Sharpe, S. (2016) 'Global energy stress: challenges and opportunities for child friendly cities' in Ansell, N. and Klocker, N. (eds) Geographies of Global Issues: Change and Threat, Vol. 7 of Skelton, T. (ed.) Geographies of Children and Young People. Springer Singapore.

United Nations (1989). United Nations Convention on the Rights of the Child. http://www2.ohchr.org/english/law/crc.htm Accessed 24 November 2015.

United Nations, Department of Economic and Social Affairs, Population Division (2015). World Population Prospects: The 2015 Revision, Key Findings and Advance Tables. Working Paper No. ESA/P/WP.241. 
Wells, K. (2016) 'Governing the Global Child: Bio-Politics and Liberal Subjectivities' in Ansell, N. and Klocker, N. (eds) Geographies of Global Issues: Change and Threat, Vol. 7 of Skelton, T. (ed.) Geographies of Children and Young People. Springer Singapore.

Young, S. and Kumar, S. (2016) 'Learning to Improvise: Youth Entrepreneurs in Liberalizing India' in Ansell, N. and Klocker, N. (eds) Geographies of Global Issues: Change and Threat, Vol. 7 of Skelton, T. (ed.) Geographies of Children and Young People. Springer Singapore. 